\title{
African Diaspora Archaeology Newsletter
}

Volume 9

Issue 2 June 2006

Article 14

6-1-2006

\section{The Claims of Kinfolk: African American Property and Community in the Nineteenth-Century South}

Dylan C. Penningroth

Northwestern University,dcp@northwestern.edu

Martin J. Hardeman

Earstern Illinois University, mjhardeman@eiu.edu

Follow this and additional works at: https://scholarworks.umass.edu/adan

\section{Recommended Citation}

Penningroth, Dylan C. and Hardeman, Martin J. (2006) "The Claims of Kinfolk: African American Property and Community in the Nineteenth-Century South," African Diaspora Archaeology Newsletter: Vol. 9 : Iss. 2 , Article 14.

Available at: https://scholarworks.umass.edu/adan/vol9/iss2/14 


\section{Book Review}

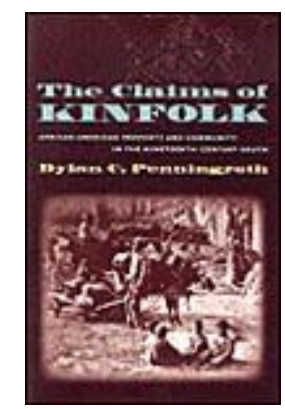

\section{H-NET BOOK REVIEW}

Published by H-South, http://www.h-net.org/ south/ (April, 2006).

Dylan C. Penningroth, The Claims of Kinfolk: African American Property and Community in the Nineteenth-Century South. Chapel Hill: University of North Carolina Press, 2003. 192 pp. Index. \$49.95 (cloth), ISBN 0-8078-2797-5; \$19.95 (paper), ISBN 0-8078-5476-X.

Reviewed for H-South by Martin J. Hardeman, Department of History, Eastern Illinois University.

\section{Property and Kinship}

Winner of the Organization of American Historian's 2004 Avery O. Craven award, Dylan C. Penningroth's Claims of Kinfolk presents a fresh interpretation of African-American life before and after emancipation. Displacing -- or at least modifying -- traditional dichotomies such as black versus white, resistance versus accommodation, and African "survivals" versus Creole acculturation, he inserts property ownership and the complex relationships within kin networks at the center of his analysis.

As Penningroth acknowledges, other historians, such as Phillip D. Morgan, have examined property ownership among slaves, and still others -- Ira Berlin, John W. Blassingame, Eugene D. Genovese, Herbert Gutman, and Deborah Gray White, for example -- have explored the importance of family, kin, and community to nineteenth-century black American life. But Penningroth has combined both to create a new investigative key. Also, by extending his analysis to 1880 , he demonstrates the continuing connection between property holding and kinship.

At the same time, he reminds his reader that under the antebellum American legal system, slaves were barred from owning property and had no legal claims to kinship. Any acquisition of property came at the sufferance of their masters and surrounding white communities. Such property had to be displayed and commonly acknowledged. And, as a general rule, property could only be acquired with the assistance of others -- most often members of a kin network. Yet despite these restrictions, Penningroth insists, property holding was widespread. 
Evidence supporting this assertion comes from a variety of sources, including slave narratives, travelers' accounts, newspapers, plantation ledgers, and court documents. Penningroth's richest source, however, is the post-Civil War records of the Southern Claims Commission, a federal agency created to compensate loyal southerners for property confiscated by Union forces during the war. More than 22,000 claims were filed. "About 5,000 of the allowed claims ... have been preserved with their testimony," he writes, and "nearly 500 of these were filed by former slaves" (p. 10).

Yet, because property ownership was most frequently a joint rather than an individual achievement, problems arose that were foreign to Anglo-American jurisprudence. The resolution of these issues, therefore, was generally left to the slave communities. Postwar reliance on committees made up of kinsmen or family elders as well as appeals to ministers and other local notables seem to reflect earlier methods of settling disputes and negotiating differences. Significantly, the same methods were used for managing interpersonal issues as well as those related to property.

Former slaves adapted to freedom. After 1865, tens of thousands traveled considerable distances to reconstitute kin networks. Encouraged to regularize their relations by state and federal authorities, couples married. They affirmed legal responsibility for their children. And while their informal economy and its dependence on "acknowledgment and display" gradually diminished, ex-slaves increasingly took advantage of the judicial forums provided by the provost marshal, Freedman's Bureau courts, and, after 1871, the Southern Claims Commission.

By the middle of the nineteenth century, American legal theorists had transformed the relationship between property and the law. According to Penningroth, the officials who went South "represented a northern society that ... had come to embrace two major assumptions about property: that law defined property and that property was an indivisible, individual possession" (p. 132). These assumptions, however, were shared completely by neither the black people of the region nor the white. For both, property existed within a social framework and for the freedman especially, the "indivisible, individual" nature of the property was problematic.

In the post-Civil War South of white landowners and African-American sharecroppers and tenants, these assumptions could not be easily applied. Ownership of land was more or less clear, but the more valuable ownership of the crops on the land was a matter of claim and counter-claim. Who owned the cotton, tobacco, or rice? At what point did control migrate from one party to the other? These were questions of continuous dispute.

Even the minority of freedmen who owned land, often purchased it with the aid of family members -- real or fictive. Black freeholders also depended on white supply merchants who advanced credit in return for an interest in the crop. Such post-emancipation realities complicated assumptions about property. In addition, Penningroth points out, they helped produce conflict and division as well. 
Investigating the internal workings of a community or family is full of interpretative difficulties; although Penningroth's discussion of the freedmen and their extended families frequently uses words like "hints" and "suggests," he believes some things are certain. The extended families and kin networks of African Americans grew in size, for example. Kinship also became more exclusive, more aware of the distance between itself and outsiders. Husbands and parents (in part because of their new legal status) asserted power over the ability of wives and children to claim property or even control their own free time. As a consequence, internal disagreements were more apt to become public and rancorous.

Evidence of such disputes, however, did not mean that the "black family was weak or broken." On the contrary, Penningroth writes, "such conflict reflects how expansive kinship became after emancipation, how strong its claims on people, and how important it remained for people's access to property and labor" (p. 186).

The insights of Penningroth's study rest heavily on the ideas of anthropologists, archeologists and historians involved in African Studies. His first chapter, in fact, explores questions of slavery, emancipation, property ownership, and the meaning of kinship among the Fante of the British Gold Coast (Ghana) from 1868 to 1930. This chapter reflects prodigious research in Ghana's national archives. It investigates the similarities and dissimilarities between West African slaves and freedmen, and those of the American South. But too often the comparison seems to be one of apples and oranges. The social, historical, and cultural gaps between the two regions ultimately appear unbridgeable.

Dylan C. Penningroth's Claims of Kinfolk is well worth reading. His interpretation of slavery and freedom is new and fruitful. The study is reminiscent of both Blassingame's The Slave Community and Steven Hahn's A Nation under Our Feet, with their emphasis on the sometimes claustrophobic interior relationships of black families, kin networks, and communities.[1] And that is not bad company to be in.

Note

[1]. John W. Blassingame, The Slave Community: Plantation Life in the Antebellum South (New York, Oxford University Press, 1972); and Steven Hahn, A Nation Under Our Feet: Black Political Struggles in the Rural South, From Slavery to the Great Migration (Cambridge, Mass.: Belknap Press of Harvard University Press, 2003).

Copyright (c) 2006 by H-Net, all rights reserved. H-Net permits the redistribution and reprinting of this work for nonprofit, educational purposes. 